\title{
A time series of SAR data for monitoring changes in boundaries of glacier zones on the Antarctic Peninsula
}

\author{
Jorge ARIGONY-NETO, ${ }^{1,2}$ Frank RAU, ${ }^{1}$ Helmut SAURER, ${ }^{1}$ Ricardo JAÑA, ${ }^{1,3}$ \\ Jefferson Cardia SIMÕES, ${ }^{2}$ Steffen VOGT ${ }^{1}$ \\ ${ }^{1}$ Institut für Physische Geographie, Albert-Ludwigs-Universität Freiburg, Werderring 4, D-79085 Freiburg, Germany \\ E-mail: arigony@googlemail.com \\ ${ }^{2}$ Núcleo de Pesquisas Antárticas e Climáticas, Universidade Federal do Rio Grande do Sul, Avenida Bento Gonçalves 9500, \\ 91.501-970 Porto Alegre, Brazil \\ ${ }^{3}$ Instituto Antártico Chileno, Plaza Muñoz Gamero 1055, Punta Arenas, Chile
}

\begin{abstract}
Drastic changes have been detected in glacial systems of the Antarctic Peninsula in the last few decades and are well documented in numerous scientific publications. However, the spatial and temporal distribution of glacier changes on the Antarctic Peninsula remains largely restricted to ice fronts. To expand the current monitoring of a few glaciers, unevenly distributed along the peninsula, to a representative set, we developed a method to simplify the detection of boundaries between glacier zones using satellite SAR data. The evolution of glacier zones is greatly influenced by local and regional climatic and meteorological settings. Their variations in response to changes in energy or mass balance are considered as good indicators of climatic changes. In this paper, we describe the results of knowledge-based image analysis algorithms on test areas located at Trinity Peninsula and near Marguerite Bay. In general, the two analyzed areas show different patterns of glacier zone development. The bare-ice zone occurs mainly on glaciers located on the eastern side of Trinity Peninsula. Its upper boundary shows a good correlation with the mean summer air temperature. Finally, the position of the dry-snow line shows different spatial patterns of change in both study areas.
\end{abstract}

\section{INTRODUCTION}

Drastic changes have been detected in glacial systems of the Antarctic Peninsula in the last few decades. The observed phenomena comprise the disintegration of ice shelves (Rott and others, 1998; Skvarca and others, 1999; Rack and Rott, 2004), acceleration and thinning of glaciers (De Angelis and Skvarca, 2003; Rignot and others, 2004; Scambos and others, 2004) and retreat of glacier fronts (Rau and others, 2004; Cook and others, 2005). Although the time response of such processes to climate change remains uncertain, the dependency of the detected glacial changes on variations in climate parameters seems evident. However, due to the lack of consistent systematic observations of the higher parts of the glacial systems in particular, it is difficult to predict further responses of glaciers to climate change. To expand the current monitoring of a few glaciers, unevenly distributed along the peninsula, to a representative set of glaciers in the near future, Arigony-Neto and others (2006) proposed a method to simplify the detection of glacial zone boundaries (i.e. snowline, wet-snow line and dry-snow line) using remote-sensing data.

The evolution of glacier zones is greatly influenced by local and regional climatic and meteorological settings. Their variations in response to changes in energy or mass balance are considered as good indicators of climatic changes (Rau and others, 2000). In addition, several authors have demonstrated the potential of radar remote sensing to identify distinct zonal boundaries within the glacier (e.g. Fahnestock and others, 1993; Forster and others, 1996; Braun and others, 2000; Rau and others, 2000; König and others, 2001). A time series of satellite synthetic aperture radar (SAR) images (European Remote-sensing Satellite-1 and -2 (ERS-1/-2) SAR, Envisat advanced SAR (ASAR) and
RADARSAT-1 SAR) enables the compilation of a database of glacier parameters for the last 14 years.

In this paper, we describe the results of knowledge-based image analysis algorithms used for classifying the climaterelated boundaries between radar glacier zones (i.e. snowline and dry-snow line) on test areas located on Trinity Peninsula (TPE) and Marguerite Bay (MGB) in the Antarctic Peninsula (Fig. 1).

\section{RADAR GLACIER ZONES}

The concept of superficial zones or facies on glaciers was first presented by Benson (1962) and Müller (1962), and reviewed by Paterson (1994). In this work, we use the reviewed concept from Paterson (1994), illustrated in Figure 2. The analogous radar glacier zones (Fig. 2) correspond to the classification scheme proposed by Rau and others (2000). The boundaries between the radar glacier zones are addressed as different snowlines (i.e. snowline, dry-snow line). This paper follows the terminology given in Figures 2 and 3.

The backscatter signal recorded on glaciers and ice sheets depends on snowpack parameters (e.g. liquid-water content, snow density, stratigraphy, grain size and surface roughness) (Rau and Braun, 2002). These parameters drive backscatter mechanisms such as volume scattering for the dry-snow radar zone and frozen percolation radar zone, low surface scattering with the radar signal being mainly absorbed by liquid water (wet snow radar zone) and surface scattering of a rough and dense surface (bare-ice radar zone) (Braun and others, 2000). The different backscatter values for each successive radar glacier zone are given in Figure 2 . 


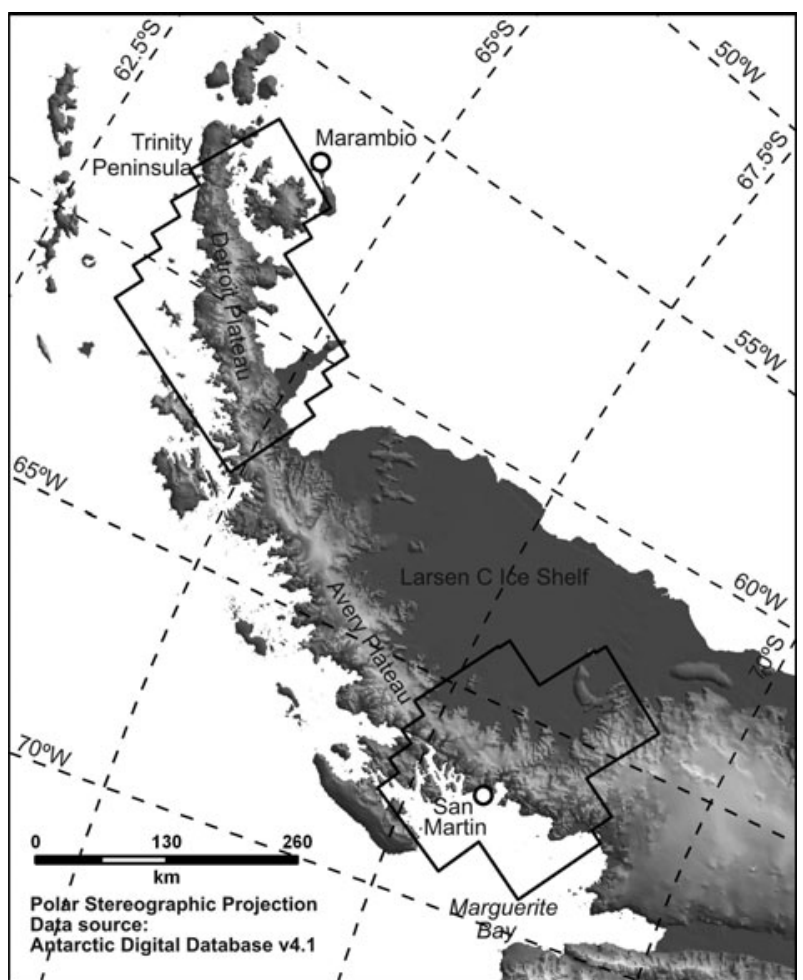

Fig. 1. Location map of the study areas on the Antarctic Peninsula.

\section{DATA AND METHODS}

Satellite data used for analysis consist of 32 images acquired in a descending orbit from 1992 to 2005 (Table 1) by the ERS-1/-2 SAR (30 images) and Envisat ASAR (2 images). Both are C-band VV polarization instruments. Figure 1 shows the area covered by the images on TPE (17 images) and MGB (15 images). Normalized backscattering coefficients $\left(\sigma^{0}\right)$ were calculated using the Basic Envisat and ERS SAR Toolbox (BEST) from the European Space Agency (ESA). BEST uses the SAR calibration algorithm developed by H. Laur and others (http://earth.esa.int/pub/ESA_DOC/ers_ sar_calibration_issue2_5f.pdf), who estimated that resulting values of $\sigma^{0}$ have an accuracy of $\pm 0.4 \mathrm{~dB}$. The excellent stability of the SAR sensors enables direct comparison of the calibrated data (Meadows and others, 1998). To reduce the speckle effect, a $5 \times 5$ median filter was applied. Finally, speckle-filtered images were orthorectified using the digital elevation model (DEM) from the RADARSAT Antarctic Mapping Project (RAMP), which was created from various datasets by $\mathrm{H}$. Liu and others (http://bipolar.colorado.edu/ data/nsidc-0082.html).

The SAR dataset was analyzed using the methodology proposed by Arigony-Neto and others (2006). This involves simplification of the image analysis by considering only areas located along glacier centre lines (Fig. 3). The socalled 'centre-line approach' minimizes the need for highresolution DEMs for terrain correction near the lateral ice divides on steep ridges. Furthermore, glaciers were selected for analysis when they were wide enough so as to avoid layover effects or shadows occurring in SAR data (ArigonyNeto and others, 2006). As the backscatter values of drysnow and frozen percolation radar zones result from volume scattering, small changes in terrain slope and aspect along the centre lines will not affect the classification of these zones. The separation between wet-snow radar zone and

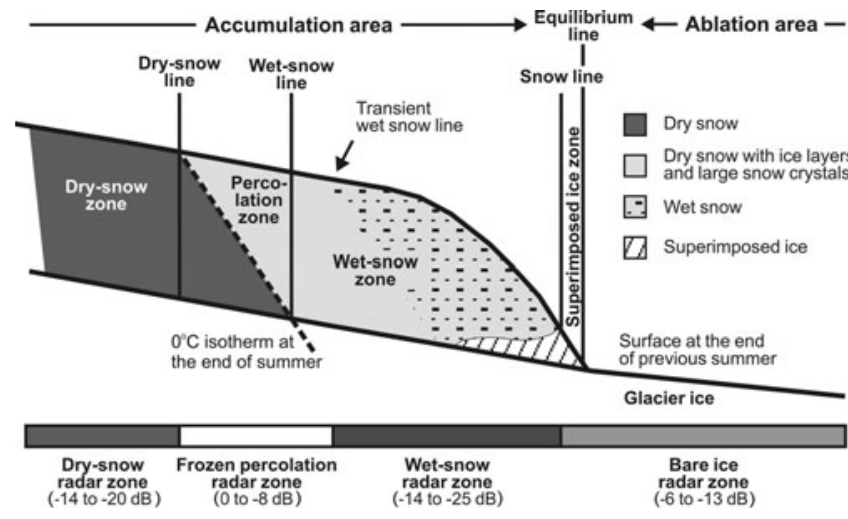

Fig. 2. Glacier zones as described by Paterson (1994) and corresponding radar glacier zones. Modified after Rau and others (2001).

bare-ice radar zone, whose thresholds in backscatter values are relatively close (Fig. 2), will profit from the restriction of the analysis to areas with smooth slopes near the centre line.

Image analyses along the glacier centre lines were carried out using a knowledge-based image analysis algorithm (Fig. 4). Rules for pixel classification were based on backscattering thresholds determined by Rau and others (2001) (see Fig. 2) and the following thresholds in altitude:

bare-ice radar zone: altitude $<500 \mathrm{~m}$;

wet-snow radar zone: altitude $<1200 \mathrm{~m}$ at TPE or $<800 \mathrm{~m}$ at MGB;

dry-snow radar zone: altitude $>1200 \mathrm{~m}$ at TPE or $>800 \mathrm{~m}$ at MGB.

Elevation information was derived from the RAMP DEM. Misclassified pixels usually correspond to steep slopes where the plateaus break down to the glaciers, or crevasse fields inside major classes such as the wet-snow radar zone. After the classification, small patches of $<2000$ pixels were eliminated, removing the misclassified areas. Boundaries between classified glacier zones were extracted automatically by the algorithm. Whenever the boundary was located within $50 \mathrm{~m}$ of the threshold in altitude, a record was added to the classification report and the position of the boundary was revised by the analyst.

\section{RESULTS AND DISCUSSION}

In total, 124 glaciers were investigated: 71 glaciers on TPE and 53 in MGB. TPE covers the northern tip of the Antarctic Peninsula (Fig. 1). There, 36 of the 71 glaciers studied flow to the eastern side, and the other 35 flow westwards. Glaciers monitored in the MGB area include 12 glaciers flowing to the Larsen $C$ ice shelf, and 41 glaciers flowing into MGB itself. The results of the image analysis are as follows.

\section{Snowline}

The development of a bare-ice radar zone was detected on 45 glaciers in total (40 glaciers on TPE and 5 in MGB). However, for glaciers on the west Antarctic Peninsula, the occurrence of the bare-ice radar zone is patchy and irregularly distributed in time. Therefore, only results from 26 glaciers in the east TPE are shown in Figure 5 and discussed here. This region coincides with the area of highest annual positive degree-days in the Antarctic Peninsula, 
modelled by Vaughan (2006). The maximum value of mean snowline altitude (i.e. mean value of snowline altitude calculated for each balance year using only data from glaciers where a bare-ice radar zone was detected) was $392 \mathrm{~m}$ (standard error $(\mathrm{SE})=41 \mathrm{~m}$ ) for the balance year $1999 / 2000$. This agrees with the lowest value of annual net mass balance $(-0.56 \mathrm{~m}$ w.e.) recorded for this balance year by Skvarca and others (2004) for the time series 1999/2000 2002/03 of 'Glaciar Bahía del Diablo', Vega Island ( $63^{\circ} 50^{\prime}$ S, $57^{\circ} 25^{\prime} \mathrm{W}$ ). In addition, the mean snowline altitude on the east coast of the TPE shows a good correlation with variations in the mean summer (December-February) air-temperature records at Marambio station (Fig. 5). Mean summer air temperatures are responsible for glacier surface melting and run-off in this region (Skvarca and De Angelis, 2003). However, the mean snowline altitude $(233 \mathrm{~m}$; SE $=58 \mathrm{~m})$ detected for the balance year 1992/93 does not agree with the mean summer air temperature recorded for this period. The lack of precipitation data or field information in addition to images acquired prior to the end of the annual ablation season makes it difficult to interpret this phenomenon, because a new snowfall event followed by snowmelting and metamorphism could mask the bare-ice zone detectable by SAR sensors.

The variability in the averaged position of boundaries between glacier zones is related to local variations in mass and energy balance (Schneider, 1999). The good correlation

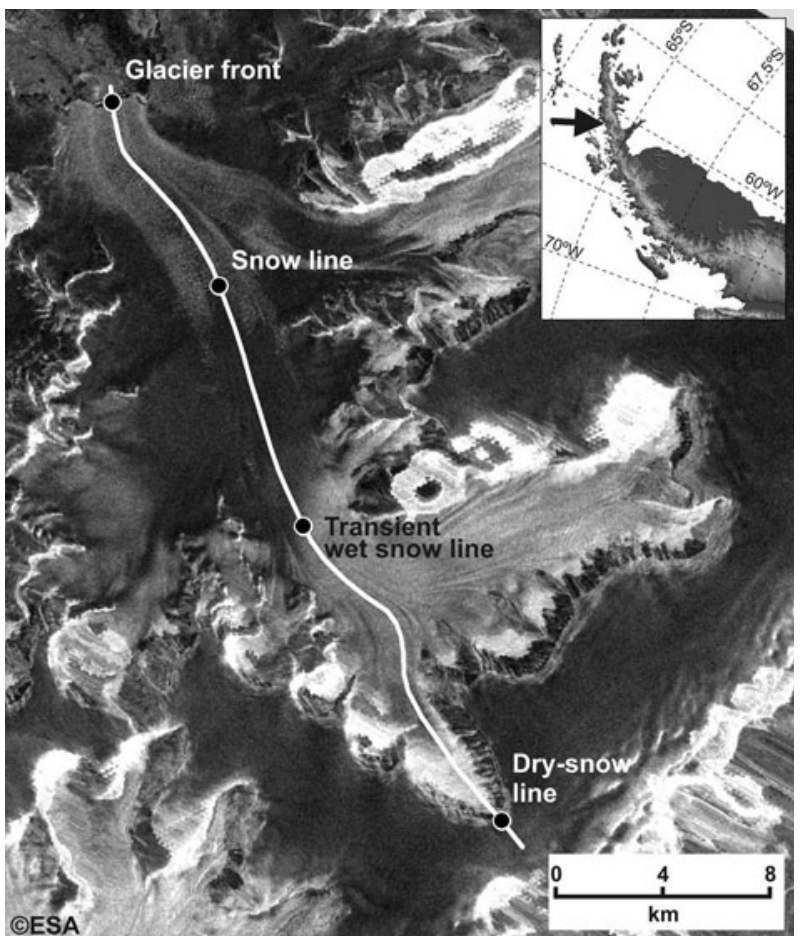

Fig. 3. Subset of the ERS-2 SAR image acquired on 23 February 2000 (orbit 25328, frame 4941) showing the position of boundaries between radar glacier zones along the glacier centre line.

Table 1. Satellite imagery used in this work. TPE: Trinity Peninsula; MGB: Marguerite Bay; DSL: dry-snow line; SL: snowline

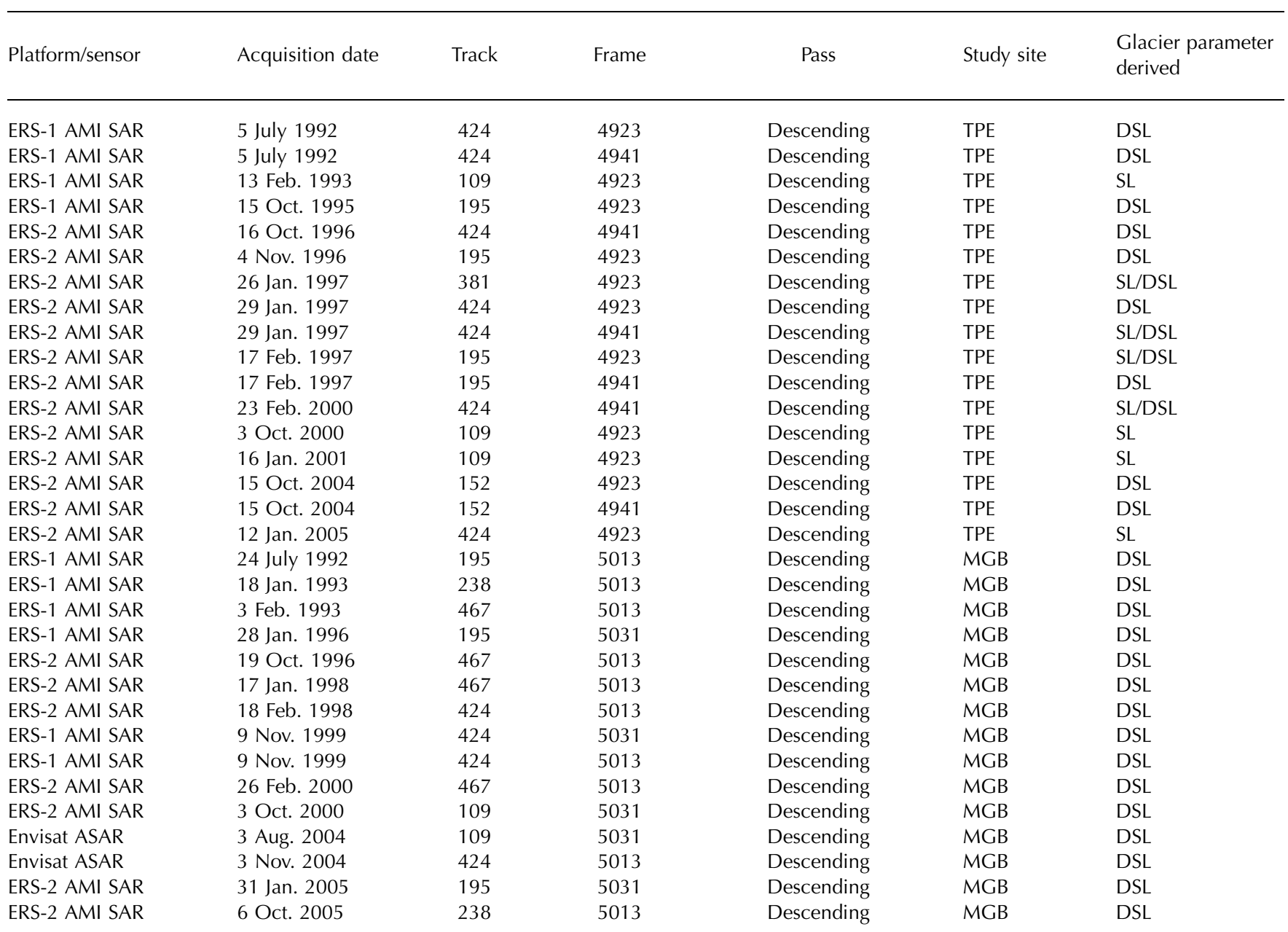




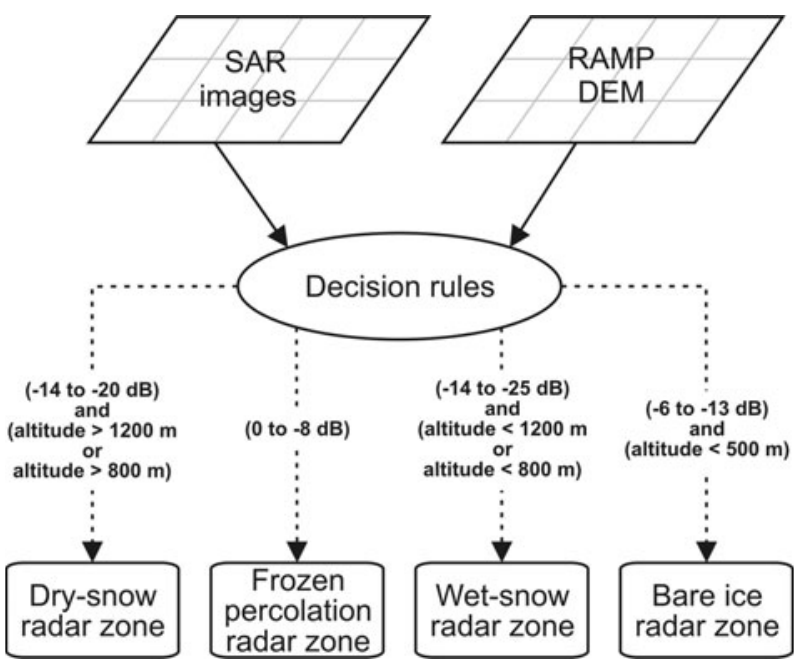

Fig. 4. Schematic representation of the knowledge-based algorithm developed for classifying radar glacier zones on the Antarctic Peninsula using SAR imagery.

of the mean snowline altitude with the mean summer air temperature shows that the SAR-derived mean snowline altitude can be used to test the hypothesis that glaciers on the northeast TPE are reacting to the positive trends in annual positive degree-days described by Vaughan (2006) for this region.

\section{Dry-snow line}

Variations in location of the dry-snow radar zone were observed on 47 glaciers located on Detroit Plateau (30 glaciers) and the central plateau of MGB (17 glaciers). On Detroit Plateau, the dry-snow line is located between 1292 and $2050 \mathrm{~m}$ altitude, whereas it reaches from 785 to $1714 \mathrm{~m}$ on the central plateau of MGB. The differences of dry-snow line altitude between the two study areas agree with the difference in mean annual surface temperature as recorded for this region (i.e. $\sim 4^{\circ} \mathrm{C}$; Morris and Vaughan, 2003).

As the basis for the statistical analysis, the altitudinal differences of the dry-snow line in metres per year were calculated for each glacier. Then annual changes in dry-snow line altitude were averaged in the western and eastern sectors of both study areas for three time periods between 1992 and 2005 (Fig. 6). Different patterns of change in the dry-snow line altitude were detected for all sectors over the period 1992-2005 (Fig. 6a-d). While the northern sectors had a positive trend in average change of dry-snow line altitude, the recorded change shows a slight downward trend in the southernmost parts of the Antarctic Peninsula (Fig. 6c-d).

Considering glaciers flowing to the Larsen $\mathrm{C}$ ice shelf (Fig. 6d), the observed increase in dry-snow line altitude agrees with findings from Rau (2003) for the period 1992 2000. This author shows the relationship of detected upward shift in dry-snow line altitude with an increase in hightemperature events at San Martin station (Fig. 1) during this period. Here, and during the last period recorded for TPE, it seems that extreme snowmelt events reach high-altitude areas in response to the increase in air temperature (Morris and Vaughan, 2003) and duration of warm periods (Torinesi and others, 2003).

A mean decrease in dry-snow line altitude was detected in the northern sectors for periods from 1992 to 2000. By

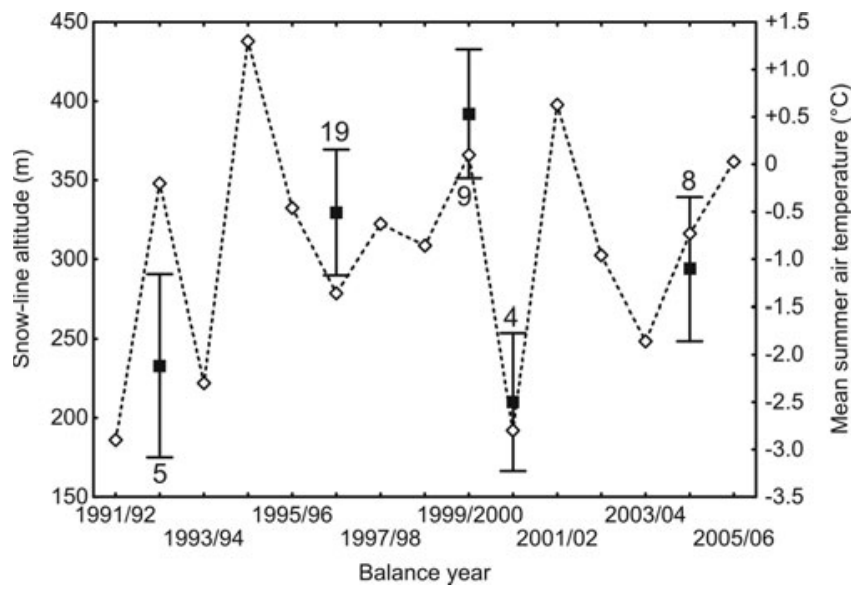

Fig. 5. Mean values of snowline altitude $(\mathrm{m})$ and standard error bars as detected on glaciers on the eastern side of TPE. The numbers indicate the sample size of glaciers for each balance year. The rhombs correspond to mean summer air temperature $\left({ }^{\circ} \mathrm{C}\right)$ recorded at Marambio station. Temperature data are from the British Antarctic Survey database (http://www.antarctica.ac.uk/met/metlog).

modelling the backscattering (C-band; VV) characteristics for dry-snow zones, Rau and others (2001) found that an increase in snow accumulation is necessary to move the drysnow line downwards. Therefore, as high accumulation (Turner and others, 2002) and precipitation (Turner and others, 1997) are recorded for the western sector of the TPE, the dry-snow line in this area appears to have reacted to increased accumulation from 1992 to 2000. Despite the high standard error values of the mean dry-snow line altitude recorded for glaciers on southern Avery Plateau, MGB, between 2001 and 2005, it is clear that the dry-snow line did not shift upward during the last period analyzed.

\section{CONCLUSIONS}

The implementation of a simple knowledge-based image analysis algorithm enabled the semi-automated analysis of a multitemporal set of satellite SAR images acquired on two test areas on the Antarctic Peninsula. The centre-line approach minimizes the need for high-resolution DEMs for terrain correction, facilitating the pre-processing of SAR data prior to image classification. However, due to the geometric effects inherent to SAR images, glaciers flowing through narrow valleys cannot be analyzed using this approach. We expect to overcome this in the near future, by using data from higher-resolution SAR sensors (e.g. TerraSAR-X).

A preliminary analysis of the spatial and temporal distribution of satellite-derived glacier parameters on the Antarctic Peninsula shows that climate-related boundaries between glacier zones (i.e. the dry-snow line and the snowline) have different spatial patterns of change in this region. These patterns vary within the study period (1992-2005), confirming the assumption by Rignot and Thomas (2002) that changes in climatological and glaciological conditions on a relatively short timescale are usual for this region. Furthermore, the good correlation of the mean snowline altitude with the mean summer air temperature shows that the mean snowline altitude as detected by SAR sensors can be used to test the hypothesis that glaciers on the northeast TPE are responding to the positive trends in annual positive degreedays described by Vaughan (2006) for this region. 

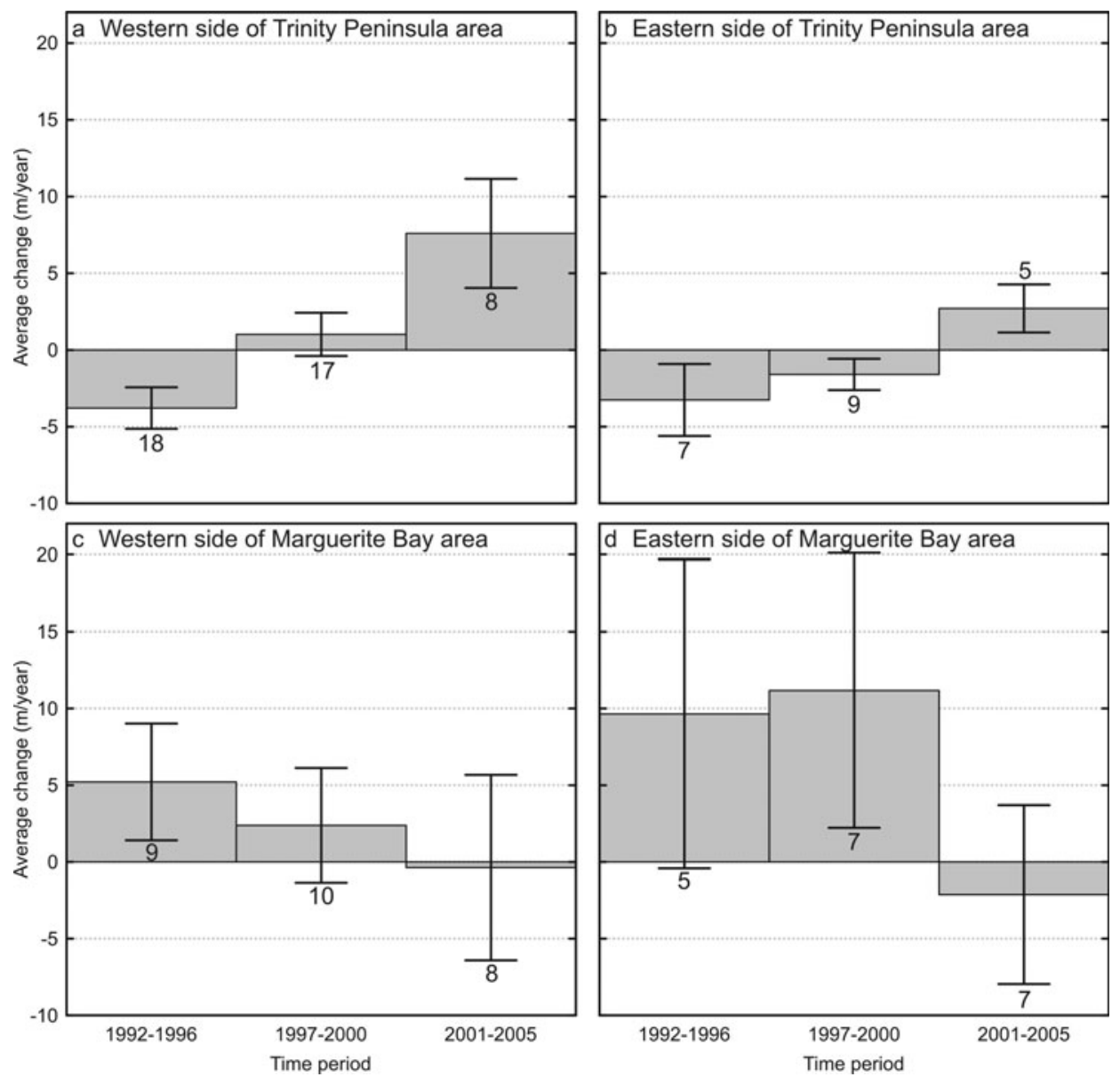

Fig. 6. Average change in dry-snow line altitude over time (1992-2005) and by sectors for each study area: (a) TPE west; (b) TPE east; (c) MGB west; and (d) MGB east. Negative and positive values correspond to mean downward and upward shifts of the dry-snow line respectively, and are relative to the mean dry-snow line altitude in the first year of the period. The numbers indicate the sample size of glaciers for each period.

\section{ACKNOWLEDGEMENTS}

This study was carried out as a contribution to the multinational project 'Global Land Ice Measurements from Space' (GLIMS) and the activities of the GLIMS Regional Center for the Antarctic Peninsula at the Department of Physical Geography, University of Freiburg. The European Space Agency is acknowledged for supplying ERS-1/-2 and Envisat ASAR data within the CryoSat Data AO Project 2658, 'Evaluating CryoSat's potential contribution to the quantification of mass balance and mass balance variations on the Antarctic Peninsula'. J. Arigony-Neto and J.C. Simões are supported by grants from the Brazilian National Council for Scientific and Technological Development (CNPq). We also thank the associate editor R. Massom and two anonymous reviewers for comments which helped to improve this paper.

\section{REFERENCES}

Arigony-Neto, J., H. Saurer, R. Jaña, F. Rau, J.C. Simões and H. Goßmann. 2006. Monitoring snow parameters on the Antarctic Peninsula using satellite data: a new methodological approach. EARSeL eProc., 5(1), 100-110.

Benson, C.S. 1962. Stratigraphic studies in the snow and firn of the Greenland ice sheet. SIPRE Res. Rep. 70.

Braun, M., F. Rau, H. Saurer and H. Goßmann. 2000. Development of radar glacier zones on the King George Island ice cap,
Antarctica, during austral summer 1996/97 as observed in ERS-2 SAR data. Ann. Glaciol., 31, 357-363.

Cook, A.J., A.J. Fox, D.G. Vaughan and J.G. Ferrigno. 2005. Retreating glacier fronts on the Antarctic Peninsula over the past half-century. Science, 308(5721), 541-544.

De Angelis, H. and P. Skvarca. 2003. Glacier surge after ice shelf collapse. Science, 299(5612), 1560-1562.

Fahnestock, M., R. Bindschadler, R. Kwok and K. Jezek. 1993. Greenland ice sheet surface properties and ice dynamics from ERS-1 SAR imagery. Science, 262(5139), 1530-1534.

Forster, R.R., B.L. Isacks and S.B. Das. 1996. Shuttle imaging radar (SIR-C/X-SAR) reveals near-surface properties of the South Patagonian icefield. J. Geophys. Res., 101(E10), 23,169-23,180.

König, M., J.G. Winther and E. Isaksson. 2001. Measuring snow and glacier ice properties from satellite. Rev. Geophys., 39(1), 1-28.

Meadows, P.J., H. Laur and B. Schättler. 1998. The calibration of ERS SAR imagery for land applications. ESA-Spec. Publ. 441, 35-42.

Morris, E.M. and D.G. Vaughan. 2003. Spatial and temporal variation of surface temperature on the Antarctic Peninsula and the limit of viability of ice shelves. Antarct. Res. Ser. 79, 61-68.

Müller, F. 1962. Zonation in the accumulation area of the glaciers of Axel Heiberg Island, N.W.T., Canada. J. Glaciol., 4(33), 302-311.

Paterson, W.S.B. 1994. The physics of glaciers. Third edition. Oxford, etc., Elsevier.

Rack, W. and H. Rott. 2004. Pattern of retreat and disintegration of the Larsen B ice shelf, Antarctic Peninsula. Ann. Glaciol., 39, 505-510.

Rau, F. 2003. The upward shift of the dry snow line on the northern Antarctic Peninsula. EARSeL eProc., 2(1), 113-121. 
Rau, F. and M. Braun. 2002. The regional distribution of the drysnow zone on the Antarctic Peninsula north of $70^{\circ} \mathrm{S}$. Ann. Glaciol., 34, 95-100.

Rau, F. and 7 others. 2000. Monitoring multi-year snow cover dynamics on the Antarctic Peninsula using SAR imagery. Polarforschung, 67(1-2), 27-40.

Rau, F., M. Braun, M. Friedrich, F. Weber and H. Goßmann. 2001. Radar glacier zones and their boundaries as indicators of glacier mass balance and climatic variability. EARSeL eProc., 1(1), 317-327.

Rau, F. and 8 others. 2004. Variations of glacier frontal positions on the northern Antarctic Peninsula. Ann. Glaciol., 39, 525-530.

Rignot, E. and R.H. Thomas. 2002. Mass balance of polar ice sheets. Science, 297(5586), 1502-1506.

Rignot, E., G. Casassa, P. Gogineni, W. Krabill, A. Rivera and R. Thomas. 2004. Accelerated ice discharge from the Antarctic Peninsula following the collapse of Larsen B ice shelf. Geophys. Res. Lett., 31(18), L18401. (10.1029/2004GL020697.)

Rott, H., W. Rack, T. Nagler and P. Skvarca. 1998. Climatically induced retreat and collapse of northern Larsen Ice Shelf, Antarctic Peninsula. Ann. Glaciol., 27, 86-92.

Scambos, T.A., J.A. Bohlander, C.A. Shuman and P. Skvarca. 2004. Glacier acceleration and thinning after ice shelf collapse in the Larsen B embayment, Antarctica. Geophys. Res. Lett., 31(18), L18402. (10.1029/2004GL020670.)
Schneider, C. 1999. Energy balance estimates during the summer season of glaciers of the Antarctic Peninsula. Global Planet. Change, 22(1-4), 117-130.

Skvarca, P. and H. De Angelis. 2003. Impact assessment of regional climate warming on glaciers and ice shelves of the northeastern Antarctic Peninsula. Antarct. Res. Ser. 79, 69-78.

Skvarca, P., W. Rack, H. Rott and T. Donángelo. 1999. Climatic trend and the retreat and disintegration of ice shelves on the Antarctic Peninsula: an overview. Polar Res., 18(2), 151-157.

Skvarca, P., H. De Angelis and E. Ermolin. 2004. Mass balance of 'Glaciar Bahía del Diablo', Vega Island, Antarctic Peninsula. Ann. Glaciol., 39, 209-213.

Torinesi, O., M. Fily and C. Genthon. 2003. Variability and trends of the summer melt period of Antarctic ice margins since 1980 from microwave sensors. J. Climate, 16(7), 1047-1060.

Turner, J., S.R. Colwell and S.A. Harangozo. 1997. Variability of precipitation over the coastal Antarctic Peninsula from synoptic observations. J. Geophys. Res., 102(D12), 13,999-14,007.

Turner, J., T.A. Lachlan-Cope, G.J. Marshal, E.M. Morris, R. Mulvaney and W. Winter. 2002. Spatial variability of Antarctic Peninsula net surface mass balance. J. Geophys. Res., 107(D13), 4173. (10.1029/2001JD000755.)

Vaughan, D. 2006. Recent trends in melting conditions on the Antarctic Peninsula and their implications for ice-sheet mass balance and sea level. Arct. Antarct. Alp. Res., 38(1), 147-152. 